\title{
Cavernous Sinus Invasion and Effect of Immunohistochemical Features on Remission in Growth Hormone Secreting Pituitary Adenomas
}

\section{Büyüme Hormonu Salgalayan Hipofiz Adenomlarnda Kavernöz Sinüs Invazyonu ve Immünobistokimyasal Özelliklerin Remisyona Etkisi}

\author{
Murat YILMAZ ${ }^{1}$, Emin VURAL ${ }^{2}$, Kenan KOC $^{3}$, Savas CEYLAN ${ }^{3}$ \\ ${ }_{1}^{1}$ Altnnova Hospital, Department of Neurosurgery, Sakarya, Turkey \\ ${ }^{2}$ Derince Research and Education Hospital, Department of Neurosurgery, Kocaeli, Turkey \\ ${ }^{3}$ Kocaeli University, School of Medicine, Department of Neurosurgery, Kocaeli, Turkey
}

Corresponding Author: Murat YILMAZ / E-mail: drmuratyilmaz@yahoo.com

\begin{abstract}
AIM: We examined the cavernous sinus invasion and tumor biological markers that influence the remission rate. Cavernous sinus (CS) invasion was evaluated radiologically. Tumor biological markers consisting of the tumor cell growth parameter Ki-67 and the cancer cell vasculature marker of vascular endothelial growth factor (VEGF) were evaluated.

MATERIAL and METHODS: We examined 28 immunohistochemically proven GH secreting pituitary adenoma patients who had been operated via endoscopic transsphenoidal surgery at Department of Neurosurgery, Kocaeli University Hospital between 2003 and 2008. Pathology preparations were stained with Ki- 67 and VEGF. We evaluated remission at the postoperative $6^{\text {th }}$ week. The basal GH level, nadir GH level and IGF-1 levels were evaluated to determine remission.

RESULTS: Remission was achieved in 6 of 18 patients (33\%) who had cavernous sinus invasion. Remission was achieved in 7 of 10 patients (70\%) who did not have cavernous sinus invasion. There was no correlation between the Ki-67 proliferation index and cavernous sinus invasion $(p=0.593)$. There was a positive correlation between VEGF expression and cavernous sinus invasion $(p=0.03)$.

CONCLUSION: The remission rate found less in the cavernous sinus invasion group. No association was found between Ki 67 proliferation index and cavernous sinus invasion. We found that a positive correlation between VEGF expression and cavernous sinus invasion. VEGF expression can therefore indirectly affect remission via cavernous sinus invasion.
\end{abstract}

KEYWORDS: GH adenoma, VEGF, Ki-67, Cavernous sinus invasion, Remission

ÖZ

AMAÇ: Çalışmada remisyona etkisi olduğu öngörülen faktörlerden; kavernöz sinüs invazyonu ve tümör biyolojisi ile ilgili özellikler gözden geçirildi. Bu amaçla kavernöz sinüs invazyonu radyolojik olarak değerlendirildi. Ayrıca tümör biyolojisini gösteren; tümör büyüme potansiyelinde etkili Ki-67 ve tümör damarlanmasını gösteren VEGF immünohistokimyasal olarak incelendi.

YÖNTEM ve GEREÇLER: Çalışmaya 2003-2008 tarihleri arasında Kocaeli Üniversitesi Hastanesi Nöroşirürji Kliniği'nde endoskopik transfenoidal yolla ameliyat edilen 28 büyüme hormonu (GH) adenomu hastası dahil edildi. Doku örneklerine Ki-67 ve VEGF immünohistokimyasal boyamaları uygulandı. Kısa dönem remisyon değerlendirmesi için postoperatif 6 . haftada IGF-1 ve OGTT sonrası GH düzeyleri ölçümlerine bakıldı.

BULGULAR: Kavernöz sinüs invazyonu olan hastalarda kısa dönem remisyon oranı 6/18 (\%33) idi. Kavernöz sinüs invazyonu olmayan 10 hastanın 7'sinde remisyon sağlandı (\%70). Ki-67 proliferasyon indeksi ile kavernöz sinüs invazyonu arasında anlamlı bir korelasyon olmadığı $(p=0,593)$, VEGF ekspresyonunun kavernöz sinüs invazyonu açısından önemli bir gösterge olduğu $(p=0,03)$ saptandı.

SONUÇ: Kavernöz sinüs invazyonu gösteren GH adenomu olgularında kısa dönem remisyon oranlarının daha düşük görüldüğü, Ki-67'nin kavernöz sinüs invazyonu ve remisyonu etkilemediği, VEGF ekspresyonunun kavernöz sinüs invazyonunu artırarak indirekt yolla remisyon üzerinde etkili olabileceği sonucuna varıldı.

ANAHTAR SÖZCÜKLER: GH adenomu, VEGF, Ki-67, Kavernöz sinüs invazyonu, Remisyon 


\section{INTRODUCTION}

Pituitary adenoma is the third most common primary brain tumor after the gliomas and meningiomas. This tumor type makes up $10-15 \%$ of primary brain tumors.

GH (Growth Hormone) secreting pituitary adenoma patients come to hospital with symptoms of acromegaly, gigantism or tumor mass effect. Surgery is the first choice treatment method for acromegaly $(34,54)$. These tumors are histologically benign and treatment outcome depends on tumor size and invasion to nearby structures. If cavernous sinus invasion is present in GH secreting pituitary adenomas, endocrinological remission cannot be achieved with surgery alone. Adjuvant radiosurgery or medication modalities can be used in these patients $(28,41,44)$. Being aware of cavernous sinus invasion in the preoperative period is important for surgery and adjuvant therapy planning.

There are some arguments about the method of cavernous sinus invasion in pituitary gland adenomas. Cavernous sinus invasion can be seen because of tumor biology or a cavernous sinus medial wall defect $(25,39,55)$. Some authors believe there is an effect of a medial wall defect on cavernous sinus invasion $(32,55)$ while some other studies report that cavernous sinus invasion can be seen because of the nature of pituitary adenoma $(18,38,39)$.

Various growth, invasion and recurrence patterns can be seen in pituitary adenomas. Proliferation markers, growth factors and genetic analyses are used to understand these biological differences.

In this study, we examined $28 \mathrm{GH}$ secreting pituitary adenoma patients who underwent endoscopic transsphenoidal surgery at Kocaeli University Hospital. We evaluated the cavernous sinus invasion and tumor biological markers that influence the remission ratio. Tumor biological markers are tumor cell growing parameter $\mathrm{Ki}-67$ and the cancer cell vasculature marker of vascular endothelial growth factor (VEGF).

\section{MATERIAL and METHODS}

\section{Patient Group}

In this study, we examined 28 immunohistochemicallyproven $\mathrm{GH}$-secreting pituitary adenoma patients who had undergone endoscopic transsphenoidal surgery at Kocaeli University Hospital between 2003 and 2008. There were 13 female patients and 15 male patients aged 29 to 71 years, with a follow-up time from 6 to 69 months and a mean duration of 27.6 months. There were 4 patients who were positive for prolactin (PRL) immunohistochemical staining and 3 who were positive for ACTH immunohistochemical staining also. All patients were followed up with endocrinology department preoperatively and postoperatively.

\section{Cavernous Sinus Invasion and Radiological Evaluation}

Cavernous sinus (CS) invasion was evaluated radiologically. In the preoperative period, MRI findings were evaluated. Knosp grade 4, 3 or more venous or lateral venous compartment compression and encasement of internal carotid artery (ICA) of more than $45 \%$ were accepted as indicating cavernous sinus invasion. Intraoperative findings were taken into consideration to determine cavernous sinus invasion of pituitary adenomas precisely.

We used a $30 \mathrm{~cm}$ diameter head coil and 1.5 Tesla Philips MRI device for examination. T1, T2 and postcontrast T1 coronal and sagittal $3 \mathrm{~mm}$ slice images were examined with the radiology department selecting midsellar coronal MRI images. In this plane, we can see the intracavernous and supracavernous segments of ICA easily. In the preoperative period, cavernous sinus invasion was evaluated according to the Knosp classification, cavernous sinus venous compartment compression, and percentage of intracavernous ICA encasement.

\section{Knosp Classification and Cavernous Sinus Venous Compartment}

CS invasion was classified into 5 grades according to Knosp's grading system as follows: Grade 0, adenomas with no CS invasion; Grade 1, adenomas not pass the intercarotid line; Grade 2, adenomas pass the intercarotid line but not extending beyond the lateral aspects of the internal carotid arteries (ICAs); Grade 3, adenomas pass the lateral aspects of the ICAs but not encasing the ICAs; and Grade 4, adenomas with total encasement of the intracavernous ICAs. CS invasion evaluation was made as follows: for Grade 0 cavernous sinus invasion is absent and for Grade 4 cavernous sinus invasion is present. For Knosp grade 1, 2 and 3 we used other parameters for cavernous sinus invasion.

In this study, the cavernous space was divided into four venous compartments with regard to the ICA (Figure 1): The medial compartment, which is between the ICA and the pituitary fossa; the superior compartment, which is above the ICA; the lateral compartment, which is the venous group lateral to the ICA; and the inferior compartment, which is below the ICA. If there was compression of 3 or more venous compartments or the lateral venous compartment, we accepted cavernous sinus invasion to be present (27).

The presence of $45 \%$ or more encasement of ICA was evaluated as cavernous sinus invasion and $25 \%$ or less encasement of ICA was evaluated as absence of cavernous sinus invasion.

Tumor size and volume calculation

Tumor size more than $1 \mathrm{~cm}$ was classified as macroadenoma and less than $1 \mathrm{~cm}$ was classified as microadenoma. The volume of the adenomas was calculated by the formula for an ellipsoid: height $x$ width $x$ thickness $x 1 / 2 \mathrm{~cm}^{3}$ (32).

\section{Laboratory Examination and Biochemical Remission Evaluation}

In the preoperative period, basal GH and IGF-1 serum levels of the patients were evaluated. At the postoperative $6^{\text {th }}$ week we evaluated remission analyses. The basal $\mathrm{GH}$ level, nadir $\mathrm{GH}$ level and IGF-1 levels were evaluated to determine remission. In this study, biochemical cure was accepted if nadir $\mathrm{GH}$ level 
was under $1 \mathrm{ng} / \mathrm{mL}$ and IGF-1 level was normal for age and $\operatorname{sex}(18)$.

\section{Histopathology Examination}

GH (DAKO, Denmark), PRL (DAKO, Denmark), ACTH (DAKO, Denmark), Ki-67 (DAKO, Denmark), and VEGF (Neomarkers, USA) antibodies were applied to the pathology specimens. Sections were placed on Poly-L-Lysin covered glass and then kept for 1 night at the $56^{\circ} \mathrm{C}$ incubator.

Sections are placed sequentially in xylol (30 minutes), absolute alcohol (15 minutes), and $96 \%$ alcohol (15 minutes). All sections were washed with water. Pathology specimens that were examined for $\mathrm{GH}, \mathrm{PRL}, \mathrm{Ki}-67$ and $\mathrm{ACTH}$ antibody were boiled in $\mathrm{pH} 6$ citrate buffer. Pathology specimens that were examined for VEGF antibody were boiled in pH8 EDTA buffer. After cooling of these specimens, they were kept in 3\% hydrogen peroxide solution for 15 minutes.

Specimens that were stained with GH, PRL, Ki-67 and ACTH were kept with the antibody for 30 minutes. For VEGF antibody staining, overnight incubation was performed.

All specimens were placed sequentially in biotinylated antibody for 15 minutes, streptovidin antibody for 15 minutes, and AEC chromogen for 15 minutes. The specimens were stained with Mayer's hematoxylin and then closed with a water-based closure item.

All stained preparations were examined by same pathologist who did not know the patients' clinical data. Both immunolabeled and unlabeled nuclei were evaluated and the percentage of positive cells was calculated. For VEGF, we graded cases with diffuse and dense staining as $(++)$, with diffuse but thin staining, or dense but only focal staining as $(+)$, and without staining as (-). For comparison, preparations were grouped as VEGF positive stained and VEGF negative stained specimens.

\section{Statistical Analysis}

Statistical analysis was performed using SPSS (Statistical Package for Social Sciences) for Windows 16.0. Results were analysed for statistically significant differences using the Mann-Whitney test or the Chi-square test where appropriate. A $P$ value $<0.05$ was considered significant.

\section{RESULTS}

\section{Cavernous Sinus Invasion}

In the preoperative period, cavernous sinus invasion was evaluated with MRI and tumor volumes were calculated. Knosp grade 4, the compression of 3 or more venous compartments and cavernous ICA encasement above $45 \%$ were grouped as the cavernous sinus invasion present group. 18 patients (64.3\%) had cavernous sinus invasion and 10 patients $(35.7 \%)$ did not have cavernous sinus invasion (Figure 2).

For comparison of cavernous sinus invasion with tumor volume, the Mann-Whitney $U$ test was used and the $p$ value

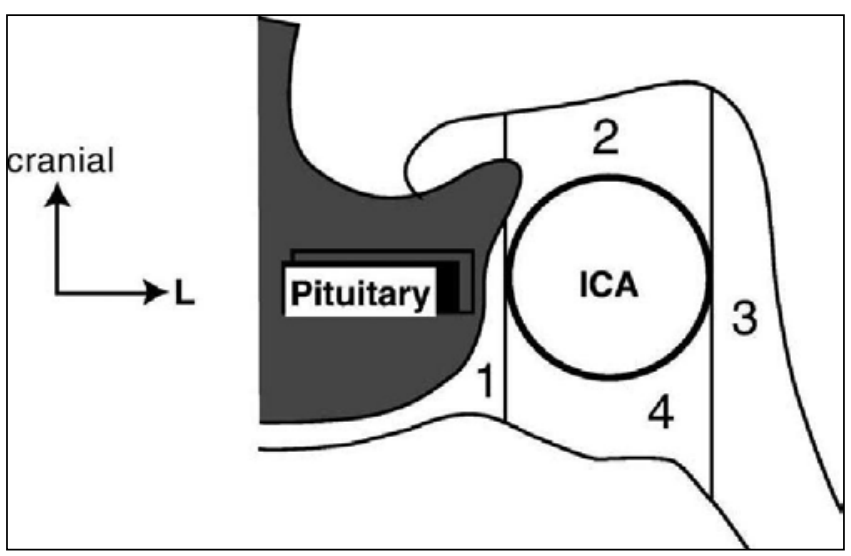

Figure 1: Cavernous sinus venous compartments: medial (1), superior (2), lateral (3), and inferior (4).

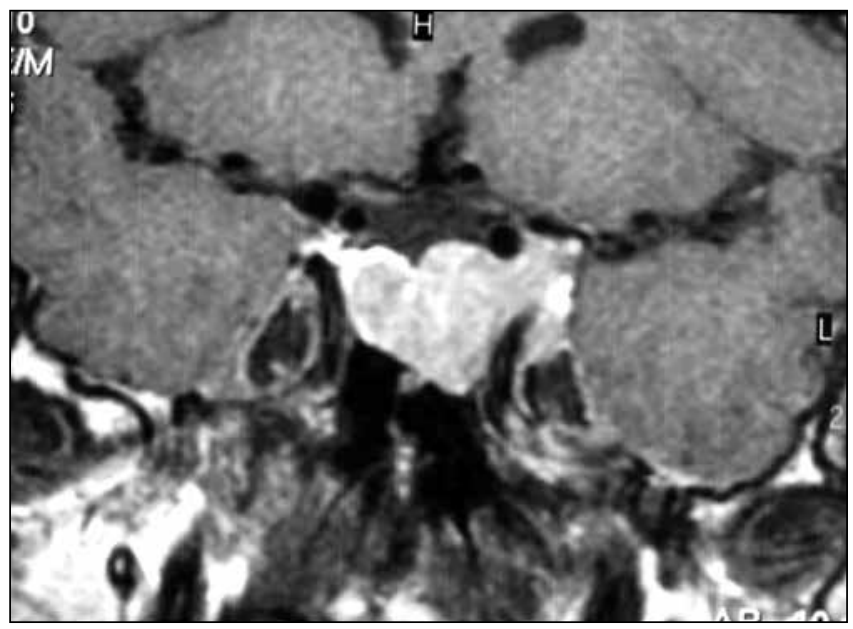

Figure 2: Left ICA total encasement, lateral venous compartment compression.

was found $0.014(p<0.05)$. There was a significant correlation between tumor volume and cavernous sinus invasion. If tumor volume increased, the cavernous sinus invasion ratio increased.

A microadenoma was found in 7 patients (25\%) and a macroadenoma in 21 patients (75\%) macroadenoma. Two microadenoma patients had cavernous sinus invasion. The median tumor volume was $1.68 \mathrm{~cm}^{3}$ and the mean tumor volume was $5.93 \mathrm{~cm}^{3}( \pm 13.54)$ (Table I).

\section{Laboratory and Remission Results}

Remission results were evaluated at the postoperative $6^{\text {th }}$ week. Patient groups were classified as remission positive and remission negative. 13 patients (46.4\%) had endocrine remission and 15 patients (53.6\%) did not have endocrine remission.

Remission was achieved in 6 of 18 patients (33\%) who were cavernous sinus invasion positive. Remission was achieved in 7 of 10 patients (70\%) who did not have cavernous sinus invasion. 
Remission was not achieved in 2 patients who had cavernous sinus invasion and were grouped as microadenoma. Remission was achieved in 3 of the 7 microadenoma patients (43\%). The Mann-Whitney $U$ test was used for the evaluation of relationship between tumor volume and remission. The $p$ value was 0.201 and there was no correlation between tumor volume and remission ( $p>0.05$ ) (Table II).

\section{Ki-67 Proliferation Index and VEGF Staining Results}

Twenty-eight patients' pathology preparations were examined by staining with Ki-67 monoclonal antibody (Figure 3, 4). The mean Ki-67 proliferation index was 0.85 ( \pm 0.78$)$. The mean Ki-67 proliferation index in cavernous sinus invasion positive cases was $0.94( \pm 0.74)$. The mean Ki-67 proliferation index without cavernous sinus invasion was $0.68( \pm 0.87)$.
The Mann-Whitney $U$ test was used for the evaluation of the relationship between the Ki- 67 proliferation index and cavernous sinus invasion. The $p$ value was 0.332 and there was no correlation between $\mathrm{Ki}-67$ and cavernous sinus invasion ( $p>0.05)$.

The Mann-Whitney $U$ test was used for the evaluation of the relationship between the $\mathrm{Ki}-67$ proliferation index and remission. The $p$ value was 0.745 and there was no correlation between Ki-67 and remission ( $p>0.05$ ).

For comparison, preparations were classified as VEGF staining positive and negative (Figure 5). Staining was not observed in 18 (64.3\%) preparations and observed in 10 (35.7\%) preparations.

Table I: Radiological Classification, Tumor Volume, Invasion, VEGF and Ki-67 Staining Properties

\begin{tabular}{|c|c|c|c|c|c|c|c|c|}
\hline Case & $\begin{array}{l}\text { Knosp } \\
\text { grade }\end{array}$ & $\begin{array}{c}\text { Micro or } \\
\text { Macroadenoma }\end{array}$ & $\begin{array}{c}\text { Tumor } \\
\text { volume } \\
\left(\mathrm{cm}^{3}\right)\end{array}$ & $\begin{array}{l}\text { Compression } \\
\text { of three venous } \\
\text { compartments or } \\
\text { the lateral venous } \\
\text { compartment }\end{array}$ & $\begin{array}{l}\text { Cavernous } \\
\text { sinus invasion }\end{array}$ & Remission & $\begin{array}{l}\text { VEGF } \\
\text { staining }\end{array}$ & Ki-67 \\
\hline 1 & 4 & Macro & 2.64 & + & + & - & + & 1.4 \\
\hline 2 & 3 & Macro & 1.70 & + & + & - & - & 0.2 \\
\hline 3 & 2 & Macro & 1.32 & - & - & + & - & 0.1 \\
\hline 4 & 3 & Macro & 13.67 & + & + & - & + & 0.9 \\
\hline 5 & 3 & Macro & 1.53 & + & + & + & ++ & 0.07 \\
\hline 6 & 4 & Macro & 23.13 & + & + & + & ++ & 1.2 \\
\hline 7 & 4 & Micro & 0.94 & + & + & - & + & 0.2 \\
\hline 8 & 2 & Macro & 2.79 & + & + & + & + & 2 \\
\hline 9 & 0 & Micro & 0.05 & - & - & - & - & 0.4 \\
\hline 10 & 3 & Macro & 3.56 & + & + & - & ++ & 1.2 \\
\hline 11 & 2 & Macro & 0.81 & - & - & + & + & 0.4 \\
\hline 12 & 2 & Micro & 0.48 & + & + & - & - & 0.6 \\
\hline 13 & 1 & Micro & 0.38 & - & - & + & - & 0.2 \\
\hline 14 & 1 & Macro & 0.64 & - & - & + & - & 1 \\
\hline 15 & 4 & Macro & 16.31 & + & + & - & - & 2 \\
\hline 16 & 4 & Macro & 3.78 & + & + & - & - & 0.4 \\
\hline 17 & 0 & Micro & 0.10 & - & - & + & - & 0.05 \\
\hline 18 & 1 & Macro & 1.94 & - & - & + & - & 3 \\
\hline 19 & 0 & Micro & 0.29 & - & - & + & - & 0.4 \\
\hline 20 & 2 & Macro & 1.18 & + & + & - & - & 2 \\
\hline 21 & 2 & Macro & 1.70 & + & + & + & + & 0.2 \\
\hline 22 & 2 & Micro & 0.36 & - & - & - & - & 0.8 \\
\hline 23 & 2 & Macro & 5.46 & + & + & + & - & 1.2 \\
\hline 24 & 2 & Macro & 0.83 & + & + & + & + & 1.2 \\
\hline 25 & 1 & Macro & 2.86 & - & - & - & - & 0.4 \\
\hline 26 & 4 & Macro & 6.86 & + & + & - & ++ & 0.1 \\
\hline 27 & 2 & Macro & 1.67 & + & + & - & - & 0.04 \\
\hline 28 & 4 & Macro & 69.30 & + & + & - & - & 2 \\
\hline
\end{tabular}


Table II: Laboratory Results and Remission

\begin{tabular}{|c|c|c|c|c|c|c|}
\hline Case & $\begin{array}{l}\text { Preoperative } \\
\text { GH (ng/mL) }\end{array}$ & $\begin{array}{c}\text { Preoperative } \\
\text { IGF-1 level (ng/mL) }\end{array}$ & $\begin{array}{l}\text { Postoperative } \\
\text { IGF-1 level (ng/mL) }\end{array}$ & $\begin{array}{l}\text { Postoperative } \\
\text { GH level (ng/mL) }\end{array}$ & $\begin{array}{l}\text { Cavernous sinus } \\
\text { invasion }\end{array}$ & Remission \\
\hline 1 & 11.1 & 820 & 632 & 0.73 & + & - \\
\hline 2 & 15.3 & 980 & 142.7 & 2.07 & + & - \\
\hline 3 & 91.0 & 1840 & 210 & 0.74 & - & + \\
\hline 4 & 30.5 & 1106 & 475 & 8.3 & + & - \\
\hline 5 & 5.3 & 465 & 305 & 0.705 & + & + \\
\hline 6 & 29.9 & 580 & 216 & 0.512 & + & + \\
\hline 7 & 6.77 & 490,9 & 277.3 & 2.13 & + & - \\
\hline 8 & 35.0 & 2150 & 304 & 0.415 & + & + \\
\hline 9 & 20.5 & 677 & 425 & 4.56 & - & - \\
\hline 10 & 32.1 & 1470 & 244 & 1.89 & + & - \\
\hline 11 & 1.11 & 360 & 262.6 & 0.17 & - & + \\
\hline 12 & 3.90 & 750 & 300 & 4.5 & + & - \\
\hline 13 & 9.95 & 401.7 & 172.9 & 0.05 & - & + \\
\hline 14 & 16.7 & 120 & 184.1 & 0.93 & - & + \\
\hline 15 & 34.0 & 921 & 496.6 & 1.97 & + & - \\
\hline 16 & 40.0 & 2504 & 560 & 2.47 & + & - \\
\hline 17 & 1.20 & 557 & 366.25 & 0.301 & - & + \\
\hline 18 & 40.0 & 830.7 & 176.51 & 0.981 & - & + \\
\hline 19 & 4.21 & 650 & 278.31 & 0.721 & - & + \\
\hline 20 & 40.0 & 890 & 550 & 1.63 & + & - \\
\hline 21 & 40.0 & 1800 & 270 & 0.484 & + & + \\
\hline 22 & 30.6 & 2350 & 1300 & 8.51 & - & - \\
\hline 23 & 12.3 & 435 & 294.81 & 0.507 & + & + \\
\hline 24 & 6.51 & 988 & 268.3 & 0.60 & + & + \\
\hline 25 & 58.3 & 698.7 & 800 & 3.19 & - & - \\
\hline 26 & 64.1 & 860 & 448.24 & 3.13 & + & - \\
\hline 27 & 20.1 & 970 & 865 & 3.25 & + & - \\
\hline 28 & 11.5 & 713 & 510.57 & 7.33 & + & - \\
\hline
\end{tabular}

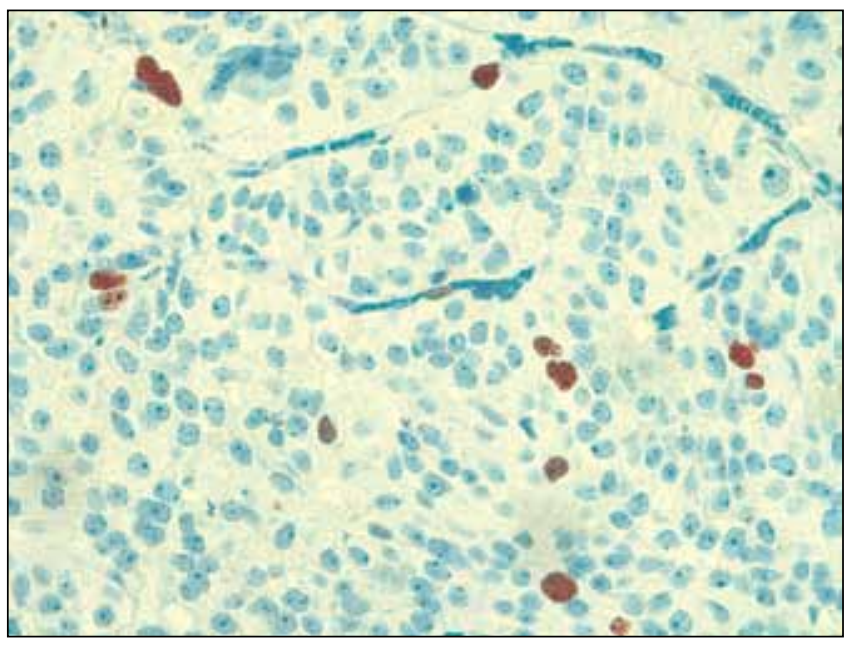

Figure 3: Ki-67 monoclonal antibody strongly positive staining.

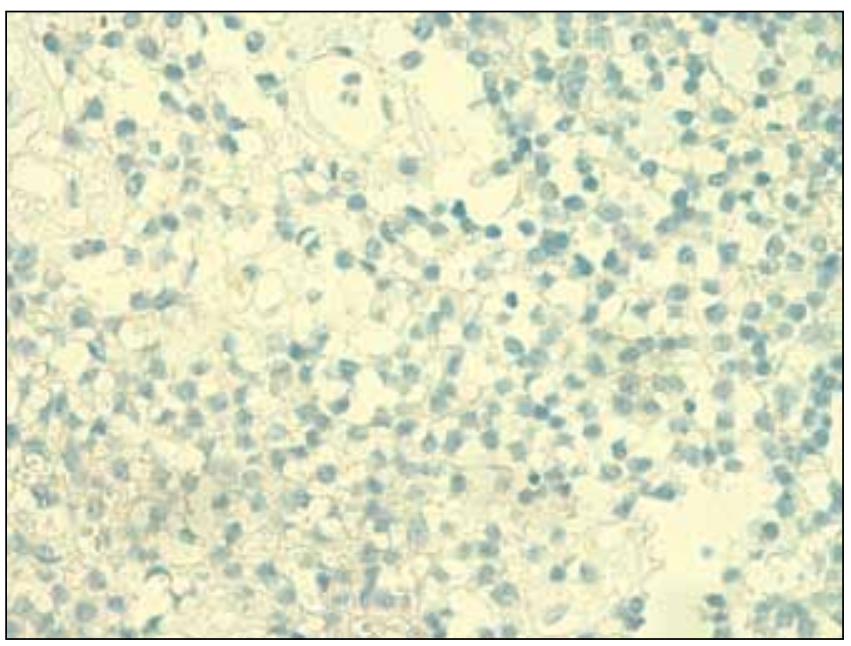

Figure 4: No staining with Ki-67 monoclonal antibody staining. 


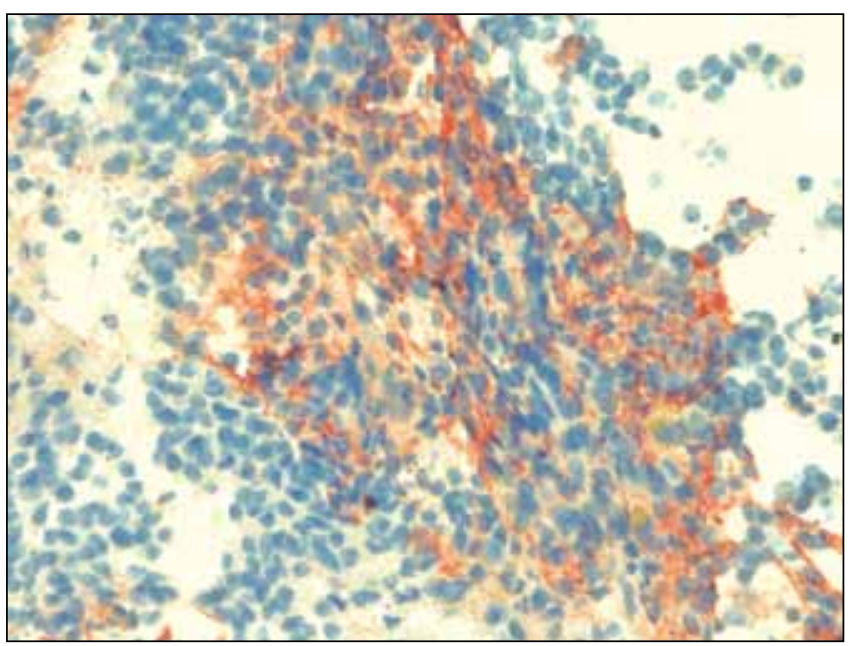

Figure 5: Strongly VEGF staining positive preparation.

The Chi-Square test was used for determining the correlation between VEGF expression and cavernous sinus invasion. A statistically positive correlation was found $(p=0.03)$ (Table I). Patients who had VEGF expression had a higher cavernous sinus invasion rate.

The Chi-square test was used for determining the correlation between VEGF expression and remission. No statistically significant correlation was found $(p=0.910)$.

\section{DISCUSSION}

Acromegaly is an important problem in $\mathrm{GH}$-secreting pituitary adenoma. If we look at retrospective cohort studies, there is increased risk of mortality compared with the normal population in the acromegaly patient group (38). Decreasing serum $\mathrm{GH}$ level to the normal level can decrease the mortality rate (2). Normalisation of serum $\mathrm{GH}$ level is the primary goal for treatment of acromegaly. In recent studies, surgery alone or with radiosurgery and medical treatment is the first-choice treatment modality for acromegaly patients (34).

Pituitary gland adenomas are slowly growing tumors but can cause chiasm compression and can invade the cavernous sinus or sphenoid sinus. Invasive adenomas can infiltrate the bone and rarely the brain (8). There is no parameter for treatment options and behavior pattern of this type of invasive pituitary adenoma.

Immediate decreasing of growth hormone levels for acromegaly patiens can be achived by surgery. For patients with microadenomas, normalization of growth hormone secretion can be achieved in approximately $70 \%$ of patients with acromegaly $(15,28,42)$. In macroadenomas, the results are less satisfactory with regard to full normalization in that only approximately $50 \%$ of such patients achieve those goals $(3,5,10,28)$. Remission cannot be achieved with only surgery and thus we have to perform radiosurgery or medical treatment as adjuvant therapy. GH values and invasion of the cavernous sinus were independent predictors of surgical failure. Many studies indicate that such patients usually require a multidisciplinary and more aggressive approach to control GH hypersecretion $(28,30,41)$. In our group, we found that cavernous sinus invasion is important for achieving remission. Remission was achieved in 6 of 18 patients (33\%) who had cavernous sinus invasion. Remission was achieved in 3 of 7 microadenoma patients (43\%). We concluded that cavernous sinus invasion is an important factor for remission.

Six to ten percent of pituitary adenomas involve the cavernous sinus $(1,12)$. These rates are found more frequently in radiological publications. Vieira et al. examined 103 pituitary adenoma patients and 206 cavernous sinuses and found cavernous sinus invasion in $25 \%$. Cavernous sinus invasion was evaluated as positive if encasement of ICA was more than $45 \%$ and compression of 3 or more venous compartments was present in their study. Cavernous sinus invasion was evaluated as absent if the medial venous compartment is intact or the gland is pushed toward the cavernous sinus wall in their study (51). Cottier et al. examined 106 pituitary adenoma patients and 212 cavernous sinuses and cavernous sinus invasion was found in $44 \%$ (94 patients). In their study, cavernous sinus invasion was uncertain for 21 patients (10\%) at surgery. An encasement percentage of the intracavernous ICA by adenoma greater than or equal to $67 \%$ was the most specific sign; if the median intercarotid line was not crossed, the superior venous compartment was visible, the cavernous sinus was normal size, or there was no bulging of its lateral dural wall, then invasion of the cavernous sinus space could be excluded reliably (9). Nakasu et al. examined 80 pituitary gland adenoma patients and found no cavernous sinus invasion in microadenoma patients. Also in their study, cavernous sinus invasion was found in $21.5 \%$ of macroadenoma patients (36). In our study, we found that most of cavernous sinus invasion present patients were macroadenoma patients.

There is disagreement about the cavernous sinus invasion theory. Some studies support a medial wall defect and others support tumor biology $(25,39,55)$. Why some tumors have cavernous sinus invasion present is unclear. Two different concepts are present in the literature. Some authors argue that a pituitary fossa lateral wall defect or weakness can be responsible for cavernous sinus invasion $(11,55)$. Some other authors argue that tumor biological behavior can be responsible for cavernous sinus invasion $(25,33,45)$.

The sella wall thickness can vary from person to person as well as in the right and left sides of the same person. Sometimes the lateral wall can be seen as loose fibrous band (9). Difference of lateral wall thickness can be responsible for growing of tumor into the cavernous sinus. As an example, if there is a singlesided lateral wall defect, one side cavernous sinus invasion can be seen. If we look at collagen immunochemistry, there are collagen type I, II, III and IV in the pituitary capsule unlikely there is only collagen type I and II in lateral wall. Matrix metalloproteinases (MMPs) are a family of zinc-containing endopeptidases that are able to degrade the extracellular matrix (39). MMP-9 is a type IV collagenase. Kawamoto et al. published the first document relationship between MMP- 
9 expression in pituitary adenomas and cavernous sinus infiltration (25). The pituitary capsule is very rich in collagen type IV. Considering this, one would expect that a pituitary tumor cell that expresses MMP-9 would degrade the capsule. As a result, cavernous sinus invasion in a pituitary adenoma can occur because of lateral wall weakness or biochemically collagen degrading enzyme secretion. $\mathrm{Ki}-67$ is found in the cell nuclei and can be seen only if the cell cycle is in the G1, $\mathrm{S}, \mathrm{G} 2$ or M phase. It cannot be seen in the G0 phase (17). Ki67 is good indicator for growth rate and neoplasia process. Thapar et al. used 3\% Ki-67 proliferation index as an invasion and not differentiation indicator and also found this cutoff point to be $97 \%$ specific and $73 \%$ sensitive (43). As the Ki-67 proliferation index was used as an indicator of cell proliferation, many studies were conducted about pituitary gland adenoma invasion $(21,22,24,26,33,55)$. Mastronardi et al. examined 103 pituitary gland adenoma patients and found the Ki-67 proliferation index to be a useful marker for the invasion character of pituitary tumors (33). There are some other studies that support this study $(21,22,26,40)$. Kawamato et al. managed another study regarding the relationship between invasion and $\mathrm{Ki}-67$ proliferation index and found no correlation (24). Tugan et al. found no correlation between the Ki-67 proliferation index and invasion or recurrence in a 44-patient study group (46). In our study, the mean Ki67 proliferation index was $0.85( \pm 0.78)$. The mean Ki-67 proliferation index mean in cavernous sinus invasion positive cases was $0.94( \pm 0.74)$. The mean $\mathrm{Ki}-67$ proliferation index without cavernous sinus invasion was $0.68( \pm 0.87)$. There was no correlation between the Ki-67 proliferation index and cavernous sinus invasion.

Angiogenesis is complex biological mechanism and related to various growth factors associated with vascular proliferation $(4,14,19)$. Angiogenesis was found to be associated with a poor prognosis, metastases, high recurrence and high mortality in tumor groups $(6,52,53)$. The role of angiogenesis has not been understood in endocrine tumors $(16,47)$. The relationship between angiogenesis and a pituitary adenoma is not adequately known $(23,48,49)$. VEGF-A is a polypeptide and can be secreted from normal or tumor cells $(13,20)$. VEGF can especially be found in the vascular endothelial cell and has an important role regarding angiogenesis, increasing cell proliferation, migration and vascular permeability $(20,29)$. VEGF expression was found to be related with prognosis in breast, lung and gastrointestinal tract cancers $(7,13,20,29)$. There is less vascular structure in pituitary adenoma tissue compared with normal pituitary gland tissue. The reason of this difference could be the presence of angiogenesis inhibiting factors $(7,14,47)$. On the other hand, vasculature of pituitary adenoma tissue is completely or incompletely from the extraportal system (7). There is some controversy about the effect of VEGF in pituitary adenoma. Viacava et al. found no difference in VEGF expression between normal pituitary gland tissue and pituitary adenoma tissue. They also found no correlation between VEGF expression and tumor size, age, sex, recurrence rate and histological type (49). Niveiro et al. found high VEGF expression in elderly patients and those with nonfunctional tumor. We also found no correlation between VEGF and proliferative activity and extracellular growth (37). Vidal et al. examined the Flk-1 receptor, normal pituitary gland and VEGF receptor found in $\mathrm{GH} 3(\mathrm{GH}-$ and PRL-secreting rat pituitary tumor cell) on 6 rat pituitary gland tissues. They concluded that Flk-1 had an important role in the neoplasia process as a receptor of VEGF. GH-secreting pituitary adenomas had more VEGF expression because of less vasculature than in other types of pituitary gland tumors (50). Lloyd et al. found VEGF expression to be highest in GH-secreting pituitary adenoma and less in PRL-secreting pituitary adenoma in 148 patients (31). Less staining was observed with VEGF in the octeotide treatment group. luchi et al. found a positive correlation between VEGF expression and cavernous sinus invasion (22). We found a positive correlation between VEGF expression and cavernous sinus invasion $(p=0.03)$.

Remission is an important problem for $\mathrm{GH}$-secreting pituitary adenoma. If remission is achieved, there is a lower mortality rate. Remission criteria have changed in past 2 decades (18). A basal $\mathrm{GH}$ level less than $2.5 \mathrm{ng} / \mathrm{mL}$, nadir $\mathrm{GH}$ level less than $1 \mathrm{ng} / \mathrm{mL}$ and IGF-1 levels have been used to determine remission. Serum hormone levels have to be evaluated to determine early remission. A GH level of less than $5 \mathrm{ng} / \mathrm{mL}$ has been used as a reference point for remission, leading to higher remission rates in previous studies. Ross and Wilson published a $79.4 \%$ remission rate in 214 transsphenoidal surgery patients (41). With the same remission criteria, Tindall et al. found a remission rate of $81.3 \%$ in 103 patients (44). The remission rate is now lower with the new criteria. Laws et al. published a remission rate of $52 \%$ in 86 patients (30). Kreutzer et al. found a $51.4 \%$ remission rate in 57 acromegaly patients. In our study, we found a $46.4 \%$ remission rate. Kreutzer et al. also found a lower remission rate with cavernous sinus invasion (28). Minniti et al. found a 38\% remission rate in the invasion present group and $81 \%$ remission rate in the microadenoma group (35). In our study, we found a $70 \%$ remission rate without cavernous sinus invasion and 33\% remission rate with cavernous sinus invasion present. We conclude that cavernous sinus invasion is an important factor regarding the remission rate.

\section{CONCLUSION}

We found a high cavernous sinus invasion rate (64\%) in $\mathrm{GH}$ secreting pituitary adenoma patients. The remission rate was found to be lower in the cavernous sinus invasion present group. The Ki-67 proliferation index was not associated with remission or cavernous sinus invasion. A correlation was found between VEGF and cavernous sinus invasion. To summarize, we found that $\mathrm{GH}$-secreting pituitary adenoma patients with cavernous sinus invasion have a lower remission rate and VEGF expression can be used to determine the behavior of pituitary adenomas. 


\section{REFERENCES}

1. Ahmadi J, North CM, Segall HD, Zee CS, Weiss MH: Cavernous sinus invasion by pituitary adenomas. AJR Am J Roentgenol 146: 257-262, 1986

2. Bates AS, Van't Hoff W, Jones JM, Clayton RN: An audit of outcome of treatment in acromegaly. Quarterly Journal of Medicine 86: 293-299, 1993

3. Beauregard C, Truong U, Hardy J, Serri O: Long-term outcome and mortality after transsphenoidal adenomectomy for acromegaly. Clin Endocrinol (Oxf) 58: 86-91, 2003

4. Bergers G, Benjamin LE: Tumorigenesis and the angiogenic switch. Nat Rev Cancer 3: 401-410, 2003

5. Biermasz NR, van Dulken $H$, Roelfsema F: Ten-year follow-up results of transsphenoidal microsurgery in acromegaly. J Clin Endocrinol Metab 85: 4596-602, 2000

6. Bochner BH, Cote RJ, Weidner N, Groshen S, Chen SC, Skinner DG, Nichols PW: Angiogenesis in bladder cancer: Relationship between microvessel density and tumor prognosis. J Natl Cancer Inst 87: 1603-1612, 1995

7. Bochner BH, Cote RJ, Weidner N, Groshen S, Chen SC, Skinner DG, Nichols PW: Expression of vascular permeability factor (vascular endothelial growth factor and its receptors in breast cancer. Hum Pathol 26: 86-91, 1995

8. Botelho $\mathrm{CH}$, Magalhaes AV, Mello PA, Schmitt FC, Casulari LA: Expression of p53, Ki-67 and c-erb B2 in growth hormone and/or prolactin-secreting pituitary adenomas. Arq Neuropsiquiatr 64(1):60-66, 2006

9. Cottier JP, Destrieux C, Brunereau L, Bertrand P, Moreau L, Jan M, Herbreteau D: Cavernous sinus invasion by pituitary adenoma: MR imaging. Radiology 215: 463-469, 2000

10. De P, Rees DA, Davies N, John R, Neal J, Mills RG, Vafidis J, Davies JS, Scanlon MF: Transsphenoidal surgery for acromegaly in Wales: Results based on stringent criteria of remission. J Clin Endocrinol Metab 88: 3567-3572, 2003

11. Dolenc VV: Anatomy and surgery of the cavernous sinus. Yugoslavia: Springer, Verlag/Wien, 1989

12. Falbusch $R$, Buchfejder $M$ : Transsphenoidal surgery of parasellar pituitary adenomas. Acta Neurochir 92: 93-99, 1988

13. Ferrara N, Gerber HP, LeCouter J: The biology of VEGF and its receptors. Nat Med 9: 669-676, 2003

14. Folkman J, Shing Y: Angiogenesis. J Biol Chem 267: 1093110934, 1992

15. Freda PU, Wardlaw SL, Post KD: Long-term endocrinological follow-up evaluation in 115 patients who underwent transsphenoidal surgery for acromegaly. J Neurosurg 89: 353358,1998

16. Garcia de la Torre N, Wass JA, Turner HE: Antiangiogenic effects of somatostatin analogues. Clin Endocrinol (Oxf) 57: 425- 441, 2002

17. Gerdes J, Lemke $H$, Baisch $H$, Wacker HH, Schwab U, Stein $H$ : Cell cycle analysis of a cell proliferation-associated human nuclear antigen defined by the monoclonal antibody Ki-67. The Journal of Immunology 133(4) :1710-1715, 1984
18. Giustina A, Barkan A, Casanueva FF, Cavagnini F, Frohman L, Ho K, Veldhuis J, Wass J, Von Werder K, Melmed S: Criteria for cure of acromegaly: A consensus statement. J Clin Endocrinol Metab $85: 526-529,2000$

19. Gould VE, Wagner BM: Angiogenesis: An expanding universe. Hum Pathol 33 :1061-1063, 2002

20. Hicklin DJ, Ellis LM: Role of the vascular endothelial growth factor pathway in tumor growth and angiogenesis. J Clin Oncol 23: 1011-1027, 2005

21. luchi T, Saeki N, Osato K, Yamaura A: Proliferation, vascular endothelial growth factor expression and cavernous sinus invasion in growth hormone secreting pituitary adenomas. Acta Neurochir (Wien) 142(12): 1345-1351, 2000

22. Iuchi S, Saeki N, Uchino Y, Higuchi Y, Tatsuno I, Nakamura S, Yasuda T, Yamaura A: Cavernous sinus invasion and tumor proliferative potential of growth hormone-producing pituitary tumors. Endocr J 47 Suppl: S77-79, 2000

23. Jugenburg M, Kovacs K, Stefaneanu L, Scheithauer BW: Vasculature in nontumorous hypophyses, pituitary adenomas, and carcinomas: A quantitative morphologic study. Endocr Pathol 6: 115-124, 1995

24. Kawamoto H, Uozumi T, Kawamoto K, Arita K, Yano T, Hirohata $\mathrm{T}$ : Analysis of the growth rate and cavernous sinus invasion of pituitary adenomas. Acta Neurochir (Wien) 136: 37-43, 1995

25. Kawamoto H, Uozumi T, Kawamoto K, Arita K, Yano T, Hirohata T: Type IV collegenase activity and cavernous sinus invasion in human pituitary adenomas. Acta Neurochir (Wien) 138: 390-395, 1996

26. Kitz K, Knosp E, KoosWT, Korn A: Proliferation in pituitary adenomas: Measurement by MAb KI 67. Acta Neurochir Suppl (Wien) 53:60-64,1991

27. Knosp E, Steiner E, Kitz K, Matula C: Pituitary adenomas with invasion of the cavernous sinus space: A magnetic resonance imaging classification compared with surgical findings. Neurosurgery 33(4): 610-618, 1993

28. Kreutzer J, Vance ML, Lopes MB, Laws ER Jr: Surgical management of $\mathrm{GH}$-secreting pituitary adenomas: An outcome study using modern remission criteria. J Clin Endocrinol Metab 86(9): 4072-4077, 2001

29. La Rosa S, Uccella S, Finzi G, Albarello L, Sessa F, Capella C: Localization of vascular endothelial growth factor and its receptors in digestive endocrine tumors: Correlation with microvessel density and clinicopathologic features. Hum Pathol 34: 18-27, 2003

30. Laws ER, Vance ML, Thapar K: Pituitary surgery for the management of acromegaly. Horm Res 53 Suppl 3: 71-75, 2000

31. Lloyd RV, Scheithauer BW, Kuroki T, Vidal S, Kovacs K, Stefaneanu L: Vascular endothelial growth factor (VEGF) expression in human pituitary adenomas and carcinomas. Endocr Pathol 10: 229-235, 1999

32. Lurie SN, Doraiswamy PM, Husain MM, Boyko OB, Ellinwood EH Jr, Figiel GS, Krishnan KR: In vivo assessment of pituitary gland volume with magnetic resonance imaging: The effect of age. J Clin Endocrinol Metab 71(2): 505-508, 1990 
33. Mastronardi L, Guiducci A, Spera C, Puzzilli F, Liberati F, Maira G: Ki-67 labelling index and invasiveness among anterior pituitary adenomas: Analysis of 103 cases using the MIB-1 monoclonal antibody. J Clin Pathol 52: 107-111, 1999

34. Melmed S, Casanueva FF, Cavagnini F, Chanson P, Frohman L,Grossman A, Ho K, Kleinberg D, Lamberts S, Laws E, Lombardi G, Vance ML, Werder KV, Wass J and Giustina A: Guidelines for acromegaly management. Journal of Clinical Endocrinology and Metabolism 87: 4054-4058, 2002

35. Minniti G, Jaffrain-Rea ML, Esposito V, Santoro A, Tamburrano G, Cantore G: Evolving criteria for post-operative biochemical remission of acromegaly: Can we achieve a definitive cure? An audit of surgical results on a large series and a review of the literature. Endocr Relat Cancer 10(4): 611-619, 2003

36. Nakasu Y, Nakasu S, Ito R, Mitsuya K, Fujimoto O, Saito A: Tentorial enhancement on MR images is a sign of cavernous sinus involvement in patients with sellar tumors. Am J Neuroradiol 22:1528-1533, 2001

37. Niveiro M, Aranda Fl, Peiró G, Alenda C, Picó A: Immunohistochemical analysis of tumor angiogenic factors in human pituitary adenomas. Human Pathology 36: 10901095, 2005

38. Orme SM, McNally RJ, Cartwright RA, Belchetz PE: Mortality and cancer incidence in acromegaly: $A$ retrospective cohort study. United Kingdom Acromegaly Study Group. Journal of Clinical Endocrinology and Metabolism 83: 2730-2734, 1998

39. Peker S, Kurtkaya Yapıcıer O, Kilic T, Pamir MN: Microsurgical anatomy of the lateral walls of the pituitary fossa. Acta Neurochir (Wien) 147: 641-649, 2005

40. Pizarro CB, Oliveira MC, Coutinho LB, Ferreira NP: Measurement of Ki-67 antigen in 159 pituitary adenomas using the MIB-1 monoclonal antibody. Braz J Med Biol Res 37(2): 235-243, 2004

41. Ross DA, Wilson CB: Results of transsphenoidal microsurgery for growth hormone-secreting pituitary adenoma in a series of 214 patients. J Neurosurg 68(6): 854-867, 1988

42. Swearingen B, Barker FG 2nd, Katznelson L, Biller BM, Grinspoon S, Klibanski A, Moayeri N, Black PM, Zervas NT: Long-term mortality after transsphenoidal surgery and adjunctive therapy for acromegaly. J Clin Endocrinol Metab 83: 3419-3426, 1998

43. Thapar K, Kovacs K, Scheithauer BW, Stefaneanu L, Horvath E, Pernicone PJ, Murray D, Laws ER Jr: Proliferative activity and invasiveness among pituitary adenomas and carcinomas: An analysis using the MIB-1 antibody. Neurosurgery 38: 99-107, 1996
44. Tindall GT, Oyesiku NM, Watts NB, Clark RV, Christy JH, Adams DA: Transsphenoidal adenomectomy for growth hormonesecreting pituitary adenomas in acromegaly: Outcome analysis and determinants of failure. J Neurosurg 78(2): 205-215, 1993

45. Trouillas J, Daniel L, Guigard MP, Tong S, Gouvernet J, Jouanneau E, Jan M, Perrin G, Fischer G, Tabarin A, Rougon $G$, Figarella-Branger D: Polysialylated neural cell adhesion molecules expressed in human pituitary tumors and related to extrasellar invasion. J Neurosurg 98:1084-1093, 2003

46. Tugan D, Demirtas E, Ozdamar N, Gulmen V, Saygili F: Clinicopathological features of pituitary adenomas. Correlation between $\mathrm{Ki}-67$ proliferation index and recurrence or invasion. Nörol Bil D 16:2, 1999

47. Turner HE, Harris AL, Melmed S, Wass JA: Angiogenesis in endocrine tumors. Endocr Rev 24: 600-632, 2003

48. Turner HE, Nagy Z, Gatter KC, Esiri MM, Wass JA, Harris AL: Proliferation, bcl-2 expression and angiogenesis in pituitary adenomas: Relationship to tumour behaviour. Br J Cancer 82: 1441-1445, 2000

49. Viacava P, Gasperi M, Acerbi G, Manetti L, Cecconi E, Bonadio AG, Naccarato AG, Acerbi F, Parenti G, Lupi I, Genovesi M, Martino E: Microvascular density and vascular endothelial growth factor expression in normal pituitary tissue and pituitary adenomas. J Endocrinol Invest 26: 23-28, 2003

50. Vidal S, Lloyd RV, Moya L, Scheithauer BW, Kovacs K: Expression and distribution of vascular endothelial growth factor receptor Flk-1 in the rat pituitary. J Histochem Cytochem 50(4): 533-540, 2002

51. Vieira JO Jr, Cukiert A, Liberman B: Evaluation of magnetic resonance imaging criteria for cavernous sinus invasion in patients with pituitary adenomas: Logistic regression analysis and correlation with surgical findings. Surgical Neurology 65(2): 130-135, 2006

52. Weidner $\mathrm{N}$ : Intratumoral vascularity as a prognostic factor in cancers of the urogenital tract. Eur J Cancer 32A: 2506-2512, 1996

53. Weidner N, Semple JP, Welch WR, Folkman J: Tumor angiogenesis and metastasis: Correlation in invasive breast carcinoma. N Engl J Med 324: 1-8, 1991

54. Weiss M: Pituitary tumors: An endocrinological and neurosurgical challenge. Clin Neurosurg 39: 114-122, 1992

55. Yokoyama S, Hirano H, Moroki K, Goto M, Imamura S, Kuratsu $\mathrm{Jl}$ : Are nonfunctioning pituitary adenomas extending into the cavernous sinus aggressive and/or invasive? Neurosurgery 49: 857-862, 2001 